\title{
Methanol Extract of Barringtonia asiatica, Kurz. Quite Effective Induce Mortality of Spodopthera litura, Fabr. Larvae on Soybean Plants
}

\author{
Meity N Tanor \\ State University of Manado, Manado, Indonesia \\ Abdul Latief Abadi, Bambang Tri Raharjo \\ Plant Pest and Disease Major, Faculty of agriculture, Universitas Brawijaya, \\ Malang, Indonesia
}

Jantje Pelealu

Faculty of agriculture, Samratulangi University, Manado, Indonesia

Received: May 6, 2014 Accepted: May 20, 2014

doi:10.5296/jbls.v5i2.5587ＵRL: http://dx.doi.org/10.5296/jbls.v5i2.5587

\begin{abstract}
This study aim was to examine the effectiveness of methanol extract derived from keben seed (B. asiatica) on mortality of Spodopthera litura larvae on soybean plant. The instar II larvae of $S$. litura were treated by the methanol extract with various concentrations i.e. $0.0 \mathrm{ppm}$ (Control), $0.2 \mathrm{ppm}, 0.4 \mathrm{ppm}, 0.8 \mathrm{ppm}$ and $1.0 \mathrm{ppm}$ using pre-investment and post-investment. The mortality of larvae $S$. litura was counted after 24-hours of the treatment. The B. asiatica seed extract was quite effective in suppressing the intensity of damage in leaves caused by the attack of $S$. litura $F$. on soybean plants. The finding on pre-investment showed that after 24-hour treatment of methanol extract showed to have a significant impact on the mortality of $S$. litura instar II. The methanol extract dose $0.2 \mathrm{ppm}, 0.4 \mathrm{ppm}, 0.8 \mathrm{ppm}$, and $1.0 \mathrm{ppm}$ had all been able to affect larvae mortality of S. litura there are $33.33 \%, 48.89 \%, 66.67 \%$, and $88.89 \%$ respectively. Moreover, post-investment experiment showed that the methanol extract also induced mortality of $S$. litura in all doses, i.e $0.2 \mathrm{ppm}, 0.4 \mathrm{ppm}, 0.8 \mathrm{ppm}$ and $1.0 \mathrm{ppm}$ caused $44.44 \%$ (53.33\%) ( 55.56\%), (71.11\%) mortality, respectively.
\end{abstract}


Keywords: Methanol extract, B. Asiatica seed, Mortality, Larvae S. litura

\section{Introduction}

Spodopthera litura F. belongs to Lepidoptera ordo, and is one of the pests that cause serious damage to crops in the tropics and sub-tropics (Haryanti et al., 2006). To control this pest, farmers use chemical insecticides intensively (with high frequency and dose). The situation resulted in adverse impacts such as symptoms of resistance, pest resurgence, death of natural enemies of pests, increased residue on crops produced, pollution on the environment, and increased health risks for users (consumers of the crops) (Haryanti et al., 2006).

Reduction in the use of pesticides could be done by utilizing natural enemies and botanical pesticides for environmentally sustainable form of agriculture (Grace and Yuyun, 2006; Samsudin, 2008). The use of natural insecticides derived from plant extracts has been proven to be safer because they have shorter lifespan residue. After the application, natural insecticides will break down into compounds that may not toxic to humans and to the environment (Desi 2007; Syahputra, 2001).

There are more than 1000 species of plants that can be utilized as natural insecticides, antifeedant substances, repellent substances, acaricides and growth retardants (Susetyo et al., 2008). The major advantage is that natural pesticides can easily degrade. Aided by the natural components, such as sunlight, air and moisture, the degradation process of these natural insecticides happen quickly in nature. Thus, natural pesticides sprayed few days before harvesting time will not leave any residue (Sukrasno, 2003). One of the plants that have the potential to be developed as a natural pesticide is Barringtonia asiatica (L) Kurz or in Indonesia is better known as Bitung (Ecology \& Evolutionary Biology Greenhouse (EEBG), 2006). The seeds of the plant can be directly used as a natural pesticide (Kardinan, 2005). The methanol extract of derived from the seed of B. asiatica is toxic to larvae of Crocidolomia pavonana F. (Lepidoptera: Pyralidae) (Dono and Sujana, 2007) and to larvae of Epilachna sp (Herlt et al., 2002). The active compounds found in Bitung include saponins, gallic acid, hydrocyanic acid, and triterpenoids consisting of bartogenat acid, 19-epibartogenat acid, and acid-bartogenat anhidro.

Formulation of B. asiatica seed extract is also safe to apply to plants such as cabbage, broccoli, and cauliflower at the age of five weeks. The best results of $B$. asiatica seed extract formulation are 30 WP formulation with $100 \%$ mortality against $C$. pavonana larvae on day 5 (Danar and Abdurrohim, 2008). From the afore-presented descriptions, the researchers feel compelled to do this study in order to determine the effectiveness of methanol seed extract (B. asiatica) on mortality of S. litura larvae.

\section{Methods}

\section{Seed extraction of $B$. asiatica}

The experiment was conducted from February 2012 to January 2013 in the Laboratory of Biology Department, the State University of Manado and the Center for Research and Study of Plants Tomohon in North Sulawesi. B. asiatica seeds were obtained from Malalayang Coastal 
areas of Manado. The seeds were cut into parts, and the cutted-seed was weight until $6350 \mathrm{~g}$ and dried. The dried seeds were blended to form of B. asiatica seed flour, as much as $2800 \mathrm{~g}$. The dried sample ( $450 \mathrm{~g}$ ) was macerated with methanol for $3 \times 24$ hours with occasional stirring, then filtered. The filtrate was concentrated with a rotary evaporator. The total result was $50 \mathrm{~g}$ crude extract in semi-solid form of a brownish-white color and oily matter.

\section{Treatment of Methanol Extract Derived From B.asiatica Toward S. litura Larvae Instar} II

As many as 30 polybags of soybean plants, aged three weeks, were divided into two groups, each group consisted of 15 polybags; one group was for pre-investment treatment, and the other group was for the post-investment treatment. Each treatment, both pre- investment and post-investment, was divided into five dose treatment groups $(0.0 \mathrm{ppm}, 0.2 \mathrm{ppm}, 0.4 \mathrm{ppm}, 0.8$ ppm and $1.0 \mathrm{ppm}$ of $B$. asiatica methanol seed extract) with 3 duplicates. Pre-investment treatment was done by evenly spraying methanol extract to soybeans, and 15 minutes later the instar II larvae of S. litura were laid on the leaves of the plant, and subsequent observation was carried out. While the treatment of post-investment was made by giving extra squirt of the methanol extract on the leaves of soybean plants on which the instar II larvae of S. litura were laid out. After 24 hours, the number of edible leaves and mortality rate was observed. Larvae mortality was calculated by using the formula developed by Abbott (1925) in Prijono (1999).

\section{Results and Discussion}

\section{The Mortality of $S$. litura Larvae on Treatment Models of Pre-Investment and Post-Investment}

The results of the analysis of variance showed that the methanol extract of $B$. asiatica seeds at various concentration levels significantly affected the mortality of $S$. litura larvae (Table 1). The results of this study indicate that the highest mortality of $S$. litura larvae was $88.89 \%$ for the pre-investment and $71.11 \%$ for post-investment in the treatment level of methanol extract of $B$. asiatica seeds at the concentration of $1.0 \mathrm{ppm}(\mathrm{K} 4)$. The higher the concentration of $B$. asiatica seed extract applied on, the higher the mortality of $S$. litura larvae was. It is proven that the higher the concentration level of a compound, the more active ingredients it contains, thus the more effective the killing powers it has.

Table 1. The Mortality Rate of S. litura F. Larvae Due to Different Concentration Levels of The Methanol Extract of B. asiatica Seeds on Treatment Models of Pre-Investment and Post-Investment

\begin{tabular}{|c|c|c|c|}
\hline \multirow{2}{*}{ No } & \multirow{2}{*}{ Treatment } & \multicolumn{2}{|c|}{ Average Mortality (\%) } \\
\cline { 3 - 4 } & & Pre-Investment & Post-Investment \\
& & & \\
\hline 1 & K0 & $0.67 \mathrm{a}$ & $4.47 \mathrm{a}$ \\
2 & K1 & $33.33 \mathrm{~b}$ & $44.44 \mathrm{~b}$ \\
3 & K2 & $48.89 \mathrm{c}$ & $53.33 \mathrm{c}$ \\
4 & K3 & $66.67 \mathrm{~d}$ & $55.56 \mathrm{~d}$ \\
5 & K4 & $88.89 \mathrm{e}$ & $71.11 \mathrm{e}$ \\
\hline
\end{tabular}




\begin{tabular}{|c|c|c|}
\hline $\begin{array}{ll}\text { Duncan } & 0.05\end{array}$ & 1.000 & 0.138 \\
\hline
\end{tabular}

Note: Figures followed by the same numbers are not significantly different with $\alpha 0.05$ on BNT. (Duncan) $\sqrt{ }$

Furthermore, we analyzed the antifeedant ability of the extract by counting the number of leaves eaten by larvae before dying. The results indicate that the number of leaves eaten by larvae in the treatment group (sprayed with methanol extract of B. asiatica seed) was less than the number of leaves eaten by larvae in the control group (Table 2). It is proven that the extract has antifeedant properties to inhibit the appetite of $S$. litura larvae to eat the leaves. Appetite reduction is thought to be the cause of death of the observed larvae.

Table 2. Percentage of Leaves Eaten by S. litura Larvae on Day 3 Observation

\begin{tabular}{|c|c|c|}
\hline \multirow{2}{*}{ Treatment } & \multicolumn{2}{|c|}{ The average number of leaves eaten (\%) } \\
\cline { 2 - 3 } & Pre-Investment & Post-Investment \\
\hline KO & 58.33 & 42.86 \\
K1 & 41.67 & 38.09 \\
K2 & 33.33 & 30.95 \\
K3 & 19.42 & 38.09 \\
K4 & 13.89 & 33.29 \\
\hline
\end{tabular}

Treatment of $B$. asiatica methanol extract at a concentration of $0.2 \mathrm{ppm}(\mathrm{K} 1)$ on pre-investment made instar II larvae of $S$. litura consume the soybean leaves by $41.67 \%$ on day 3 after treatment, whereas, in treatment $1.0 \mathrm{ppm}(\mathrm{K} 4)$, the larvae could only eat the soybean leaves by $13.89 \%$. However, the methanol extract could reduce the ability of $S$. litura larvae in eating soybean leaves compared with the control group (58.33\%). These findings are also in line with the research findings Rusdy (2009) which state that the concentration of seed and neem leaf extracts is quite effective in suppressing the intensity of leaf damage caused by the pest of $S$. litura $F$. on lettuce plants. The pesticide compounds in the seeds of B. asiatica plant have been known to cause the death of $S$. litura, and the findings of the present study confirm that the death rate of $S$. litura depends on the concentration of $B$. asiatica extract. These results are also in line with the opinion of Yuyun and Grace (2006), in which the analysis of variance in their study show that the different concentration of seed extract and neem leaf extract used against $S$. litura $F$. on lettuce plants results in a very noticeable difference on mortality rates. Similarly, the results of the study presented by Makal and Turang (2011) also show that mortality rate of C. binotalis larvae increased with the increasing concentrations of lemongrass extracts applied.

Nursal and Etti (2005) state that steroids are found in various plants and, together with other secondary substances, act as a defense against attacks by insects. Saponins contained in food consumed by insects can decrease the activity of digestive enzymes and absorption of food, while terpenoids and flavonoids are inhibit eating and are toxic for insects. If insects take the active compound and are not resistant, they will experience death; yet, on the other hand, tolerant insects will survive to the next stadia of pupa or imago. For insects that are not resistant to the active compound, before they finally die, they will survive by maximizing the utilization of energy sources in their body. As a consequence, larvae will experience barriers to growth and development. Insecticides derived from $B$. asiatica seed extract need to be developed, since its active ingredients do not cause phytotoxic symptoms. Active compounds contained in 
methanol extract of $B$. asiatica seeds are relatively safe on plants due to non-phytotoxic symptoms (Dono and Sujana, 2007).

\section{Conclusion}

The mortality of S. litura F. larvae is determined by the level of concentration of $B$. asiatica seed extract tested, the highest mortality percentage was $57.77 \%$ obtained at $1.0 \mathrm{ppm}$ for the treatment of pre-investment, and for post-investment the highest mortality was $71.11 \%$ at 1.0 ppm treatment. The concentration of $B$. asiatica seed extract was quite effective in suppressing the intensity of damage in leaves caused by the attack of $S$. litura $F$. on soybean plants. Further research is needed to examine the active compounds contained in B. asiatica seed extract that leads to antifeedant effects and mortality in S. litura larvae.

\section{References}

Danar, D., \& Abdurrohim V. (2008). Selektivitas Formulasi Ekstrak Biji Barringtonia asiatica L. (Lecythidaceae) Terhadap Ulat Krop Kubis Crocidolomia pavonana (F) dan Parasitoid Telur Trichogramma spp. serta Dampaknya Terhadap Bibit Tanaman Brassicaceae. Prosiding Seminar Nasional Pekan Kentang. Lembang 20 s.d 21 Agustus 2008.

Desi, A. (2007). Pemanfaatan biji bengkuang Sebagai Insektisida Alami. http//www. Pkm.dikti. net/pkmi award 2006/pdf/pkmi 06 068.pdf.

Anonymous. (2006). Ecology and Evolutionary Biology Greenhouse: Barringtonia asiatica, Kurz. University of Connecticut. http://florawww.eeb.uconn.edu.

Haryanti, S. M. Suryana \& Nurrahmad. (2006). Uji Daya Insektisida Ekstrak Etanol 70 \% Biji Buah Mahkota Dewa Terhadap Ulat Grayak (Spodoptera litura Fab.) Instar II. http://www.litbang.depkes.go.id/risbinkes.

Herlt, A. J, L. N. Mander, E. Pongoh, R. J. Rumampuk \& P. Tarigan. (2002). Two Major Saponins from Seeds of Barringtonia asiatica: Putative Antifeedants toward Epilachna sp. Larvaee. Journal of Natural Products, 65, 115-120. http://dx.doi.org/10.1021/np000600b

Makal, H. V. G, \& Turang, D. A. S. (2011). Pemanfaatan Ekstrak Kasar Batang Serai Untuk Pengendalian Larvae Crosidolomia binotalis Zell pada Tanaman Kubis. Eugenia, Volume 17 No. 1 April 2011

Mordue (Luntz), A. J., M. S. J. Simmonds, S. V. Ley, W. M. Blaney, W. Mordue, M. Nasiruddin \& A. J. Nisbet. (1998). Actions of azadirachtin, a plant allelochemical, against insects. Pestic. Sci., $277-284$. http://dx.doi.org/10.1002/(SICI)1096-9063(1998110)54:3<277::AID-PS801>3.3.CO;2-9

Nursal \& Etti, S. S. (2005). Kandungan Senyawa Ekstrak Lengkuas (Loctuca Indica L.), Toksisitas dan Pengaruh Subletalnya Terhadap Mortalitas Larvae Nyamuk Aedes Aegypti L. http://library. usu. ac.id/download/fmipa/06000449.pdf.

Prijono, D. (1999). Prospek dan Strategi Pemanfaatan Insektisida Alami dalam PHT hal. 1-7 


\section{Macrothink}

Journal of Biology and Life Science ISSN 2157-6076 2014, Vol. 5, No. 2

dalam Bahan Pelatihan Pengembangan dan Pemanfaatan Insektisida Alami. Pusat Kajian Pengendalian Hama Terpadu. Institut Pertanian Bogor.

Rahmat Rukmana, Yuyun Nursal \& Etti, S. S. (2005). Kandungan Senyawa Ekstrak Lengkuas (Loctuca Indica L.), Toksisitas dan Pengaruh Subletalnya Terhadap Mortalitas Larvae Nyamuk Aedes Aegypti L. Kanisius, Yogyakarta.

Rahmat Rukmana and Yuyun Yuniarsih Oesman. (2006). Nimba Tanaman Penghasil Pestisida Alami. Kanisius, Yogyakarta.

Rusdy, A. (2009). Efektivitas Ekstrak Nimba Dalam Pengendalian Ulat Grayak (Spodoptera litura F.) Pada Tanaman Selada. J. Floratek, 4, 41-54

Samsudin. (2008). Virus Patogen Serangga: Bio-Insektisida Ramah Lingkungan, http://www.pertaniansehat.or.id.

Sukrasno. (2003). Mimba Tanaman Obat Multi Fungsi, Agromedia Pustaka. Indonesia

Susetyo, T. Ruswandi \& Etty Purwanti. (2008). Teknologi Pengendalian Organisme Pengganggu Tumbuhan (OPT) Ramah Lingkungan, Direktorat Perlindungan Tanaman Pangan Jakarta.

Syahputra, E. (2001). Hutan Kalbar Sumber Pestisida Botani: Dulu Kini Dan Kelak, http// tumouto. Net/3 semi. 12 edy saputra. Html.

\section{Copyright Disclaimer}

Copyright for this article is retained by the author(s), with first publication rights granted to the journal.

This is an open-access article distributed under the terms and conditions of the Creative Commons Attribution license (http://creativecommons.org/licenses/by/3.0/). 